Available online at http://bajas.edu.iq

https://doi.org/10.37077/25200860.2021.34.sp1.13

College of Agriculture, University of Basrah

\section{Basrah Journal of Agricultural Sciences}

E-ISSN: 2520-0860

ISSN 1814 - 5868 Basrah J. Agric. Sci., 34( Special Issue 1): 119-137, 2021

\title{
A Review of the In-Field Transporting Machines Currently Used in Oil Palm Plantations in Malaysia
}

\author{
Rafea A. M. Aljawadi ${ }^{1}$, Desa Ahmad ${ }^{2 *}$, Nazmi M. Nawi ${ }^{2}$, Muhamad S. M. Kassim² \& \\ Wan I. W. Ismail ${ }^{2}$ \\ ${ }^{1}$ Department of Agricultural Machines and Equipment, College of Agriculture and \\ Forestry, University of Mosul, Mosul 41002, Nineveh, Iraq. \\ ${ }^{2}$ Department of Biological and Agricultural Engineering, Faculty of Engineering, \\ Universiti Putra Malaysia, 43400 UPM, Serdang, Selangor, Malaysia. \\ *Corresponding author E-mail:desa@upm.edu.my
}

Received 10 April 2020; Accepted 2 August 2021; Available online 20 August 2020

\begin{abstract}
This paper focuses on the in-field transporting machines currently used in oil palm plantations in Malaysia. It highlights the field conditions, the capacity of the machines and the time of completion of the transporting process which help to identify the determinants of the development of agricultural mechanization in Malaysian oil palm plantations. Understanding of the issues will help facilitate the elimination of weaknesses and defects prior to the manufacturing or modification stage. This will assist designers and manufacturers in the development and production of improved and more efficient field transportation equipment.
\end{abstract}

Keywords: Agricultural Mechanization, In-Field FFB Transporting Machines, Oil palm Mechanization.

\section{Introduction}

The agriculture industry is one of the principal economic sectors that increase income for governments and countries (Nur et al., 2014). The development of countries, particularly in Asia and Africa, depends on the application of technology, and for the agriculture sector, the spotlight is on mechanization (Onwude et al., 2016). Malaysia is now considered as an industrialized country, but the agriculture sector which was once the mainstay of the national economy, remains a significant contributor to the country's economic development.

Vegetable oil plays an essential role in food consumption and economic growth, In this context, the increase in human consumption of expansion of economic growth of developing countries, leading to the increasing global demand for vegetable oils (Mahat, 2012). The accelerated expansion in oil palm cultivation led to a total production of 17,200 metric tons of crude palm oil in 2014 (Otieno et al., 2016). 


\section{Aljawadi et al. / Basrah J. Agric. Sci., 34(Special Issue 1):119-137, 2021}

Today, Malaysia ranks second in the world in terms of the total production of oil palm, after Indonesia.

Agricultural mechanization is the mechanical systems applying agricultural engineering principles to reduce reliance on human effort as well as reduce the health and physical risks that workers in any industrial or agricultural sector would be exposed to (Norzan et al., 2014). Collecting and evacuating the fresh fruit bunches (FFBs) and loose fruits, and transporting them are the activities in oil palm plantations. In the last 20 years, many in-field transporting machines have been developed and innovated by Malaysian universities or special institutes such as the Malaysian Palm Oil Board (MPOB), Federal Land Development Authority (FELDA) and agricultural machine manufacturers (Norzan et al., 2014). All these machines are aimed at resolving the evacuation of the oil palm fruits in Malaysian plantations.

The objectives of these earlier attempts were to reduce workforce numbers, reduce human effort and increase productivity. This paper presents the technologies that have been developed and are available and identify the various criteria needed for agricultural operations in oil palm plantations and propose suggestions for improvement.

\section{The need for in-field transporting machines for FFBs}

Efforts have been undertaken to achieve mechanization practices and improve agricultural machine procedures by MPOB, local research universities and private sectors machine manufacturers to overcome the challenges of mechanization in Malaysian oil palm plantations (Akande et al., 2013); (Norzan et al., 2014). The principal objectives of mechanization of oil palm industry are: to increase the production of palm oil, to reduce the production cost of palm oil and to lower or remove tiring manual effort associated with the cultivation, processing, and palm oil extraction. In addition it helps in the finding of a solution for the growing acute labour shortage in the plantation and also downstream sectors of the industry (Akande et al., 2013).

For the proper development of transporting tools, numerous factors must be considered, such as manual workability, the technique of traveling (manoeuvrability), time motion and most importantly, operator safety. Transporting of oil palm fruit demands much, physical effort and requires considerable energy. Therefore, precise matching of machine or equipment requirements with the human capabilities or the man-machine system is crucial for optimum performance. (Yusoff et al., 2014). One of the key reasons for a reduced palm oil extraction rate is caused by the very high percentage of uncollected loose oil palm fruits. This has worsened with labour shortages, which have repeatedly been mentioned as the most critical factor in ensuring the harvesting and collection of all FFBs and loose fruits. Availability of much-needed labour remains a critical problem faced by the oil palm plantations. These shortages will lead to reduction in transporting practices and lead to protracted transporting intervals and increased quantities of uncollected loose fruits. It has been estimated that as much as three to five percent of bunch 
weight remain uncollected and this is a significant amount of wastage. As a result, this will further reduce the oil extraction rate and thus reduce profits (Hitam et al., 1995b; Zamari et al., 1999; Deraman et al., 2009; Shuib et al., 2012). On average, about $28 \%$ of the total harvesting time is spent on the collection of loose fruits (Shuib et al., 2017).

\section{Current Technologies for In-field transporting of oil palm FFBs}

According to the principal activities in oil palm plantations, the process of transporting FFBs involves two tasks: one as collecting and transporting FFBs, and the other is collecting loose fruits and transporting them with FFBs to the loading area and the machines developed are for these two tasks. Therefore the discussion in this paper focuses on collecting and transporting machines for FFBs and loose fruits. It is imperative to schedule the source of the problem or the factors influencing the transportation process of palm oil FFBs and what problems emerge as the result of the impact of these factors. Table (1) summarizes most of all in-field transporting and loose fruit collecting problems, suggestions and the type of machines developed to solve these problems.

Table (1): Sources and types of problems and solutions or suggestions in oil palm plantations to complete the production process for FFBs.

\begin{tabular}{|c|c|c|c|}
\hline $\begin{array}{l}\text { Influential } \\
\text { Factors }\end{array}$ & $\begin{array}{l}\text { Type of } \\
\text { Problem }\end{array}$ & $\begin{array}{l}\text { Solution or } \\
\text { Suggestion }\end{array}$ & Reference \\
\hline $\begin{array}{l}\text { Farmer or } \\
\text { Labours }\end{array}$ & $\begin{array}{l}\text { - Shortage of } \\
\text { skilled labour. } \\
\text { - Tough work. }\end{array}$ & $\begin{array}{l}\text { - Training courses supported by the } \\
\text { government or private sector } \\
\text { - Increasing the use of agricultural } \\
\text { mechanization }\end{array}$ & $\begin{array}{l}\text { (Onwude } \text { et al., 2016) } \\
\text { (Ismail, 2010); (Onwude } \text { et al., } \\
\text { 2016) }\end{array}$ \\
\hline $\begin{array}{l}\text { The height } \\
\text { of Oil Palm } \\
\text { Tree and } \\
\text { Nature of } \\
\text { Soil }\end{array}$ & $\begin{array}{l}\text { - Long time to } \\
\text { collect FFB and } \\
\text { low } \\
\text { productivity. } \\
\text { - Hard to travel } \\
\text { in peat soil } \\
\text { fields. }\end{array}$ & $\begin{array}{l}\text { - Mechanical FFB Loader (Grabbie) } \\
\text { - Three Wheeler Machine } \\
\text { - WakFoot MK } 2 \\
\text { - Compact Transporter } \\
\text { - Primer Move Track } \\
\text { - Multipurpose Wheel Type } \\
\text { Transporter (Rhyno) } \\
\text { - Machine } \\
\text { system for in-field FFB Collection } \\
\text { and Transportation } \\
\text { - Mobile Bunch Catcher (MBC) } \\
\text { - Loose Fruit Collector } \\
\text { - Mechanical Loose Fruit Collector } \\
\text { (MKII) and (MKIII) } \\
\text { - Roller Picker } \\
\text { - ROPICOT 1.0 } \\
\text { - Oil Palm Loose Fruit Collecting } \\
\text { Machine with Elevated Discharge } \\
\text { Mechanism (LFC Mark IV) }\end{array}$ & $\begin{array}{l}\text { (Jahis \& Hitam, 1999); (Hitam \& } \\
\text { Shuib, 2000); (Deraman et al., } \\
\text { 2006); (Shuib et al., 2011a, b); } \\
\text { (Deraman et al., 2013); (El } \\
\text { Pebrian \& Yahya, 2013); } \\
\text { (Awaludin et al., 2016b) }\end{array}$ \\
\hline $\begin{array}{l}\text { Level } \\
\text { farmland }\end{array}$ & $\begin{array}{l}\text { - Hilly and } \\
\text { uneven land }\end{array}$ & $\begin{array}{l}\text { - Cableway System for Oil Palm } \\
\text { FFB Evacuation }\end{array}$ & (Deraman et al., 2004) \\
\hline
\end{tabular}




\section{Aljawadi et al. / Basrah J. Agric. Sci., 34(Special Issue 1):119-137, 2021}

The following sections describe the FFBs transporting and loose fruits collecting machines that have been developed and their specifications.

\section{In-field collection and transportation machines}

One of the activities for FFBs of oil palm is infield transportation process which is the collecting, and loading of FFBs with the loose fruits (Jelani et al., 1998). Transporting fresh fruit bunches (FFBs) from the field to a loading station is one operation which calls for the use of labour-saving devices. The usual loading practice involves a tractor-trailer team comprising a driver and two loaders.

PORIM now known as MPOB commissioned the firm Jamsa Sdn Bhd (sole agent for the Yanmar mini tractor) to fabricate one prototype of grabber for MPOB as a joint effort in 1992. The first prototype unit was tested in the field in a commercial plantation in Johor (Fig. 1-A). The ultimate machine could grab a maximum of three bunches simultaneously with minimum damage to the fruits. The machine has a two-section crane and a three-webbed-finger gripper. Both the grabbers are fitted with four hydraulic cylinders. The crane can reach 3.5 meters and is able to lift a maximum weight of $100 \mathrm{~kg}$. The machines are capable of 24-30 tons per day compared with the manual method of 18-28 tons per day of FFBs. Therefore, this translates into an increase of 7-33\% in the transportation output. However, the labour requirement dropped from three workers to one worker. Hence, mini-tractors with trailers were used for in-field transportation, and changing to the mechanical loader could reduce the labour requirement by $66 \%$ (Hitam \& Ibrahim, 1992). The Grabber provides several benefits such as a single person for the operation of the prime mover and the implementation of the loading, the operator controls the machine from his driving seat, and the machine can load FFBs from both sides, and the machine is easy to handle. Workers productivity is improved. The machine is economically efficient and causes minimum damage to FFBs during handling.

More development was achieved on the grabber in 1995 (Fig. 1-B). The new improved Mark 2 grabber had the addition of some electronic switches in the system to enable the grabber to perform the repetitive movements by itself. The Mark 2 was tested in commercial plantations to assess its performance. The operation of this grabber was much simpler than the manual model, and the operators could be trained, and productivity could reach 25 to 35 tons per day which were a slight increase compared to the manual model. Moreover, human fatigue was reduced as the button switches were fitted in front of the driving seat and within easy reach. The machine could still be operated manually should the automatic switches malfunction (Hitam \& Shuib, 1995a). However, both grabber and Mark 2 grabber were unable to perform the function of collecting loose fruits. 

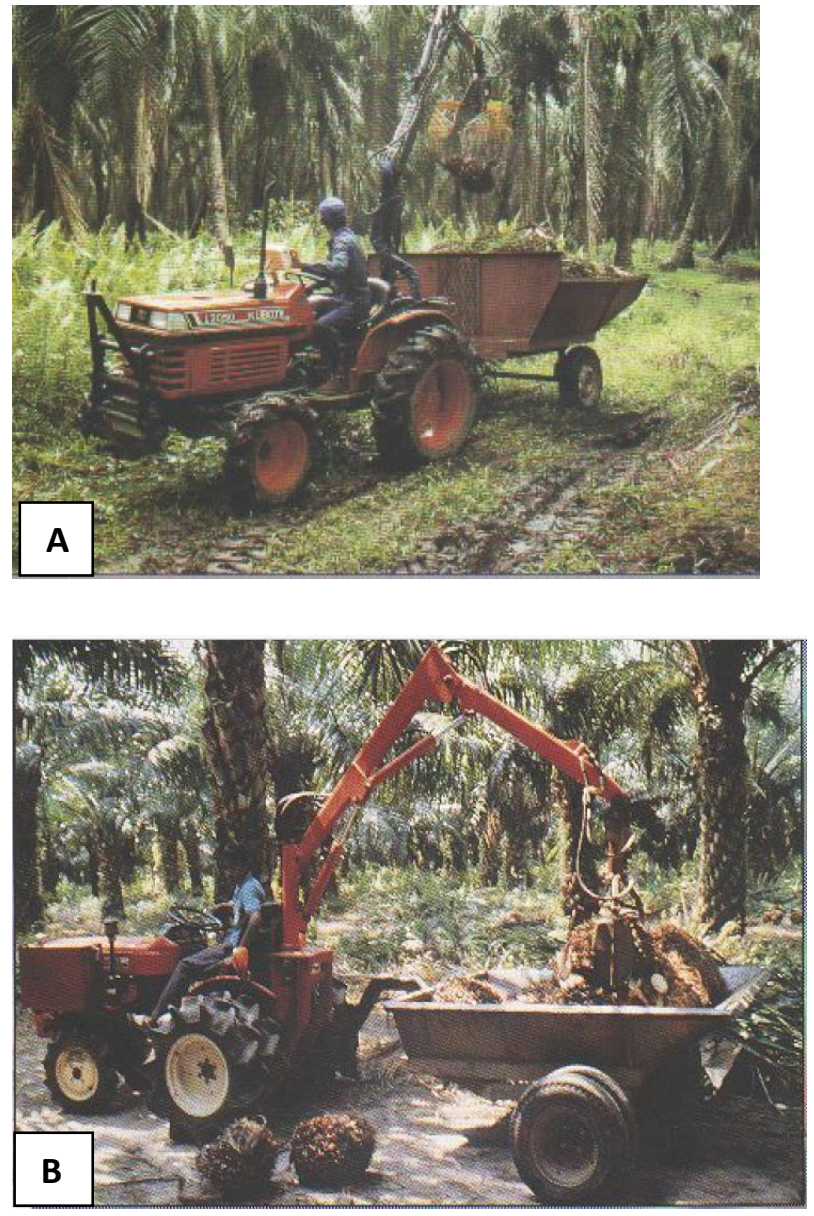

Fig. (1): Transporting machine: A. Grabber (Hitam \& Ibrahim, 1992) and B. Mark 2 Grabber in collecting FFBs in the plantation (Hitam \& Shuib, 1995a).

The MPOB later developed a mechanical loader for the oil palm field called Grabbie (Fig. 1-C) which uses a hydraulic arm to load the FFBs from the ground and is able to lift 50 $\mathrm{kg}$ weight. Grabbie productivity is $15-25$ tons per day. The bin capacity of this machine is one ton, and it can work between oil palm trees aged less than 11 years. This machine reduces the number of workers from three to one (Jahis \& Hitam, 1999).

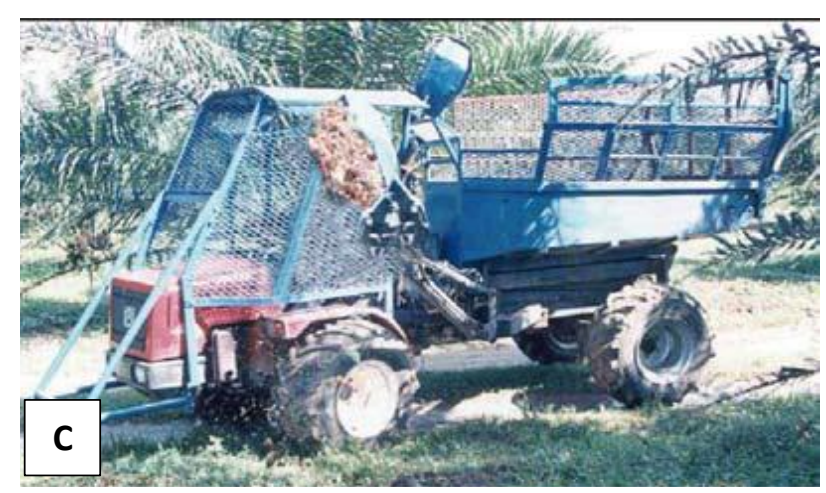

Fig. (1): C. Collection of FFBs in the oil palm field using a Grabbie (Jahis \& Hitam, 1999).

The issue of limited in-field collection and transportation of oil palm FFBs with the commonly-used mini tractor-trailer with grabber in Malaysia oil palm plantations was addressed with the development of a single chassis 67.72 HP universal prime mover operated at 2,600 rpm, has a 4WD and comes with a collection-sum-transportation attachment with a 1,500 kg payload storage bin (Fig. 2). The machine system has an output of 2.5 tons per hour or 20.2 tons per day on sloping terrain and 2.6 tons per hour or 20.9 tons per day on the gently undulating terrain. The average productive machine capacity of this mechanized system on sloping and on the gently undulating terrain is 0.78 times and 0.81 times higher than the mini tractor-trailer with the grabber.(El Pebrian and Yahya, 2013).

Fig. (3) presents a mobile ramp for mainline loading of oil palm FFBs. It is a motorized hydraulic ramp powered by a diesel engine which runs the hydraulic system for this machine. MPOB introduced this machine to load the FFBs into a lorry which waits at the roadside to transfer the FFBs to the mill. The capacity of this machine is $15-30$ tons per day 
and it has a high-lift system which can increase the trailer capacity to $300-500 \mathrm{~kg}$ (Yusof et al., 1999).

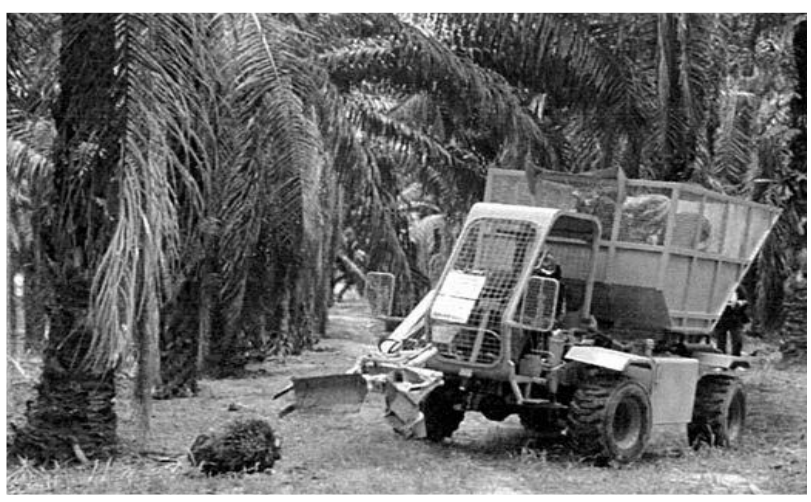

Fig. (2): The prototype of the new machine system for in-field FFB collection-transportation operation ( El Pebrian and Yahya, 2013).

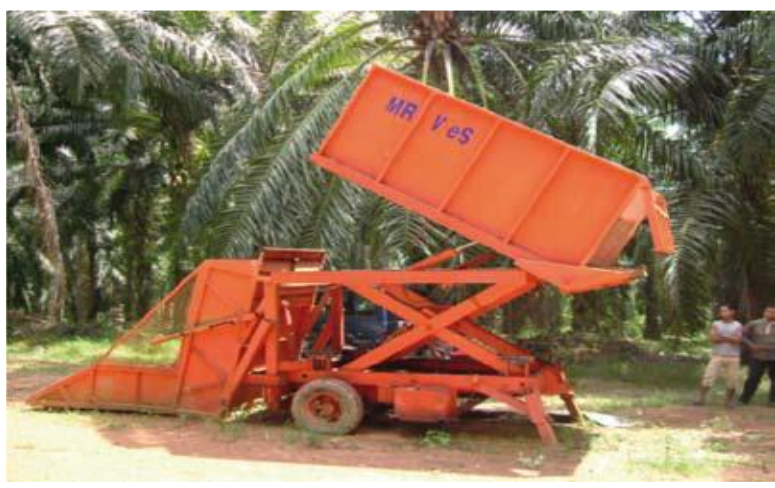

Fig. (3):The Mobile Ramp (Yusof et al., 1999).

WakFoot MK 2, is a machine specially designed and produced for peat soil terrain for which a standard transporter is not suitable due to the high slippage in this type of soil. The machine is powered by a $23 \mathrm{HP}$ diesel engine (Fig. 4) and is equipped with a power steering system, a one-ton hydraulic tipping FFB bucket, and a nine-ton electrical winch. This enables the machine to operate with six floated tires drive, each pair of wheels connected to an axial with differential gears. It can also be equipped with a grabber and hi-lift bucket.
WakFoot MK 2 productivity is 24-28 tons per day (Hitam \& Shuib, 2000). Despite that, this machine will not be able to collect FFB loose fruits.

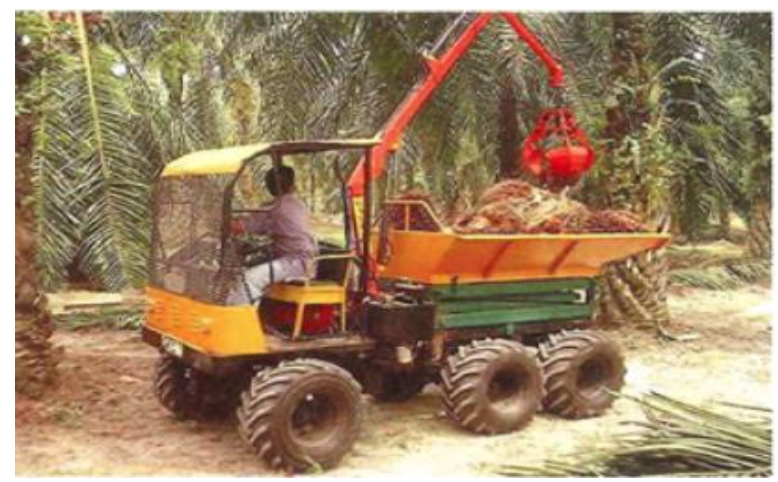

Fig. (4): The WakFoot MK2 with Grabber and hi-lift bucket (Hitam \& Shuib, 2000).

Most smallholders own a motorcycle. These motorcycles are for social use as well as for transporting workers to the field. Motorcycles can be maneuvered very well on the flat and slightly undulating oil palm fields. By tying a trailer to his motorcycle, the owner can carry a substantial load. An exclusive trailer was designed and developed to suit the smallholders' requirements. It has the ability to be fixed to any model of motorcycle, has affordable price, insignificant maintenance cost and increased productivity. It is also easy to handle, easily removable, and can be used for transporting general goods.

The trailer was fixed to a Honda Cub motorcycle with a $70 \mathrm{cc}$ engine (Fig. 5) and could carry 10 to 12 bunches of $20 \mathrm{~kg}$. The bucket was made of metal plate, and the tires were the same size as those of standard motorcycle (Hitam \& Deraman, 2001a). This simple new system offered superior maneuverability and stability. The productivity 


\section{Aljawadi et al. / Basrah J. Agric. Sci., 34(Special Issue 1):119-137, 2021}

was 3-4 tons per day which is three times more compared to productivity achieved with wheelbarrows (Hitam \& Deraman, 2001b). However, this simple system was unable to collect loose fruits.

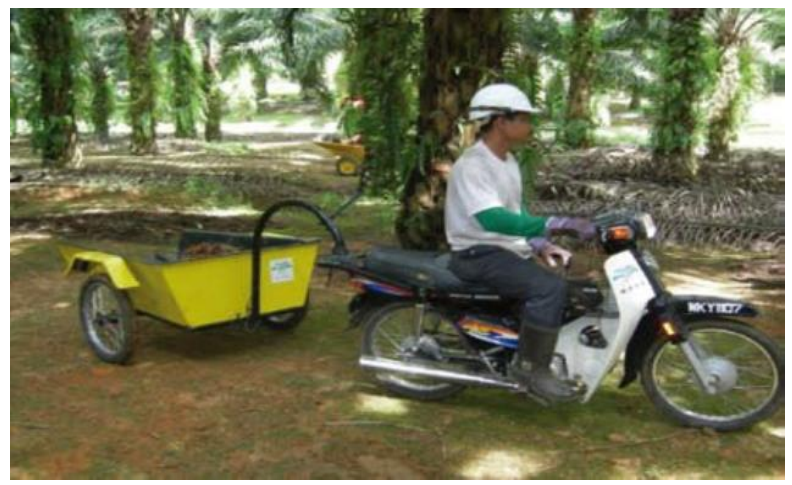

Fig. (5): Loading of FFBs by motorcycle trailer (Shuib et al., 2011a).

A powered wheelbarrow was later developed by MPOB to overcome the high prices of transporter machines used in the oil palm field. The motorized wheelbarrow has a carrying capacity of $300 \mathrm{~kg}$ (Fig. 6). This machine is not to replace workers but to assist them in their fieldwork, and thus enable them to work more efficiently and for more extended hours. Motorized wheelbarrow productivity is between 4-5 tons per day. The production cost of the motorized wheelbarrow (less than 50 units) is 4,000 to 5,500 MYR. Hence, this can be reduced if, produced in large quantity. Such an implement is desirable for small operators, as increasingly older people are involved in such work. The powered wheelbarrow can also be used for fertilizer application, as the fertilizer can be placed in the trailer and manually distributed by the operator. Therefore, this eliminates manual carrying (Hitam \& Deraman, 2001b). However, this machine is still unable to collect the loose fruits.

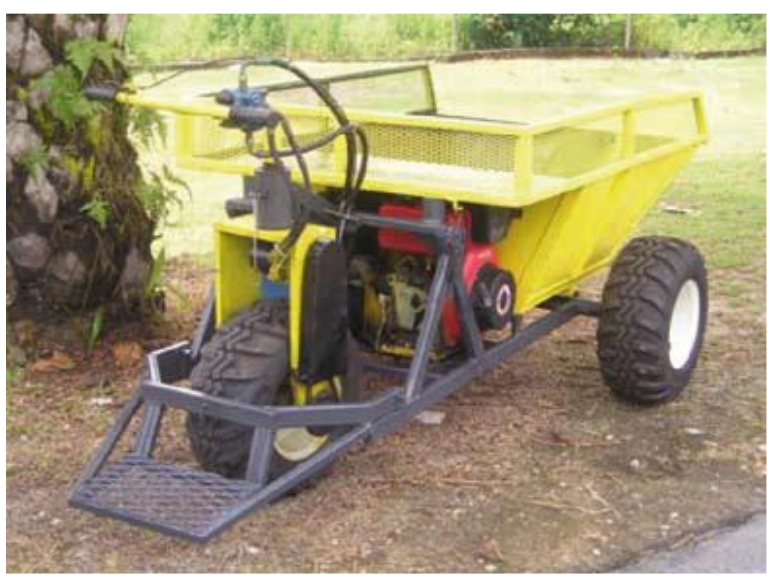

Fig. (6): The multipurpose powered wheelbarrow (Shuib et al., 2011a).

As regards the hilly terrain, a more appropriate system is the Cableway system for oil palm FFB evacuation to work in this challenging environment (Deraman et al., 2004). Most oil palm cultivation of inland areas are on steep hillsides. A few of these areas have isolated hillocks within the plantation which are not easy to access particularly in rainy seasons. The use of Cableway facilitates easy access to such areas because the load is not on but above the ground. In hilly terrain, oil palm planted on terraces are more easily accessed with machines than those that are not on terraces, It has been found that for such areas, machines with 500 to $600 \mathrm{~kg}$ capacity are appropriate. Typical terraces are narrow (in width) and unsuitable for the larger machines. In the case of sandy soils such as those found in Sabah, terraces are not feasible, and the Cableway system comes in useful.

A cable system that offers a range of essential features including a mainline cable, hauling cable, FFB bin, pylons and chain block was designed by Malaysian Palm Oil Board in collaboration with Sime Kubota Sdn Bhd (Fig. 


\section{Aljawadi et al. / Basrah J. Agric. Sci., 34(Special Issue 1):119-137, 2021}

7). The hauling cable fixed to a pulley system incorporated with a chain block linked to the FFB bin. The FFB bin is controlled by a hauling cable wound around a drum connected to the prime mover and can be positioned at the top or bottom of a hill slope. A 5 HP diesel engine powers the system. The mainline cable is $12 \mathrm{~mm}$ in diameter and hauling cable $6 \mathrm{~mm}$ in diameter. Maximum load capacity is $500 \mathrm{~kg}$ and a gradient of $60^{\circ}$. In order to avoid unnecessary sagging of the mainline and hauling cables, the distance between pylons is limited to $150 \mathrm{~m}$. This FFB container collects the FFBs from that terrace and the chain block is used to adjust the bin height to facilitate FFB loading. When the FFB bin arrives at the unloading station (either at the top or base of the slope), the bin bottom is opened to allow the FBBs to drop into a waiting lorry that will transport the FFBs to the estate ramp or the mill. The Cableway transport system also has several other features including the cable lines which are suitable for slopes up to $60^{\circ}$. With a cable line, which connects the hill locks, the fruits can transport to any side of the Cableway. The drive unit requires only $5 \mathrm{HP}$; compared with other road transports such as a mini-tractor which requires 30-35 HP. The system offers versatility and besides transporting FFBs, it is also employed to transport other products including fertilizer and other field produce and other inputs (Deraman et al., 2004). The Compact transporter for in-field activities is a single chassis machine with four low-pressure tires that offer good maneuverability between palm rows, narrow terraces, undulating terrain and soggy areas (Fig. 8).

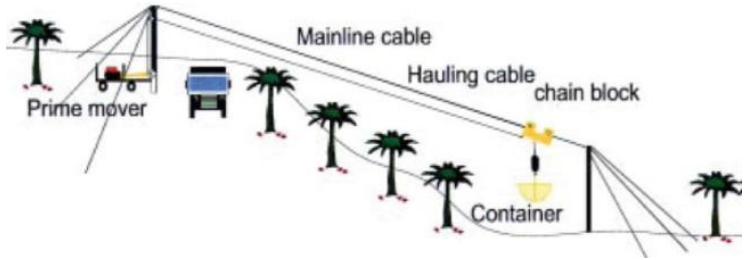

Fig. (7): Cableway system in a sloping area (Shuib et al., 2011a).

To some extent, this is a more practical machine in comparison with the mini tractor or other off-road vehicles as it can maneuver on different types of terrain and different gradients, without significantly impacting the ground condition. This benefits made the machine reliable for smallholder as well as plantation workers. In addition to in-field transportation of FFBs, the compact transporter is also useful for fertilizer application, weed control as well as general field maintenance. The productivity of compact transporter machine is 5-7 tons of FFBs per man-day with average bunch weight of $22 \mathrm{~kg}$ (Deraman et al., 2006).

Oil palm cultivation in peat areas is another challenge. Physically and chemically, the inherent properties of peat soil pose a challenge to agricultural development. An essential aspect for peatland is to travel at low ground bearing pressure. Consequently, This limits the machines used to only those that exert a low ground pressure. Particularly appropriate for such ground conditions are machines with high flotation tire or tracks.

EPA Management Sdn Bhd manufactured oil palm seed transporter known as Mechanical Buffalo in 1990 and improved by MPOB in 2006 through an increase in the engine power from 4 to $9 \mathrm{HP}$. The capacity of this machine is $400 \mathrm{~kg}$, and the bin is hi-lift for direct crop 
unloading. The price of the Mechanical Buffalo (badang) was MYR11, 600 in 1999. Productivity for Mechanical Buffalo is 7-10 tons per day (Shuib et al., 2011a).

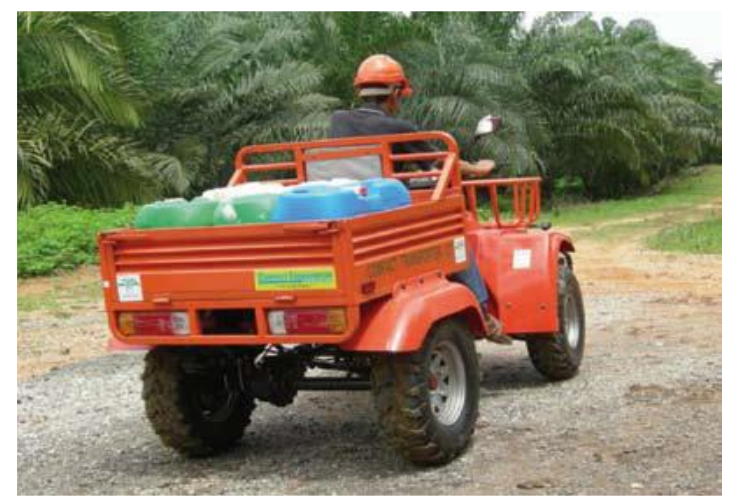

Fig. (8): The compact transporter (Deraman et al., 2006).

Another developed three-wheeler machine powered by diesel engine has $10 \mathrm{HP}$ and bucket capacity of 33 FFBs (Fig. 9) (Awaludin et al., 2015). This machine can evacuate 1980 - 2341 FFBs per day or the equivalent of $39.6-46.8$ tons per day using 0.5 litter of diesel to 1 litter. The average number of tons per worker per day is 14.4 tons per ha while the employee works 5.42 hrs per day. This machine is able to operate on all topography types. Results show that the three-wheeler evacuation machine can assist in yield FFB increase and improve oil extraction rate at the mill. All of these machines are used on flat land to collect FFBs and in-field transport them.

A half-track is a machine used for evacuating FFBs in a soft and soggy area. The rear wheels are on track to ensure good traction in wet conditions and can be used in all weather conditions (Fig. 10). It is built on a $4 \times 4$ vehicle and with standard drive components. The front wheel steering is maintained whereas its rear wheels fitted with the half-track system. The prototype payload is $500 \mathrm{~kg}$, with an unloaded weight of $1,250 \mathrm{~kg}$. The overall construction of the machine comprises a chassis, driving unit, mechanical tipping bin, and hydraulic control unit.

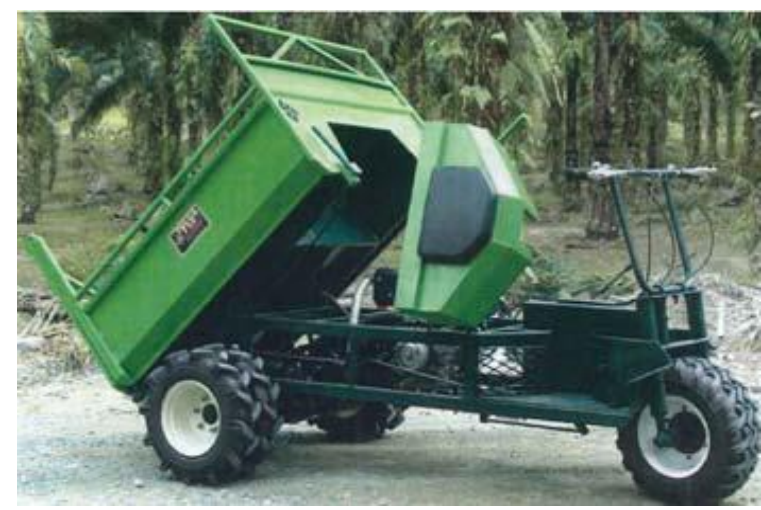

Fig. (9): Three-Wheeler Evacuation (Awaludin et al., 2015).

This machine is front-wheel steered and powered by 2-in-line cylinders, $18 \mathrm{HP}$ at 2500 rpm Lombardino diesel engine that comes with a 5-speed gearbox. The fuel tank takes 30 litters, which is sufficient for a day's work. The tracks are detachable during wet weather with soft ground conditions, the track is installed, and removed when dry conditions prevail. This prototype machine has shown that it has no traction problem on shallow peat. On average, the productivity of the machine ranges from 2.4 - 3.6 tons per hr (Shuib \& Hitam, 2002). However, the machine is still unable to collect the loose fruits.

Six-wheel-drive transporter (6WD transporter) has a single chassis configuration resting on three axles and equipped with six equal sized tires. 


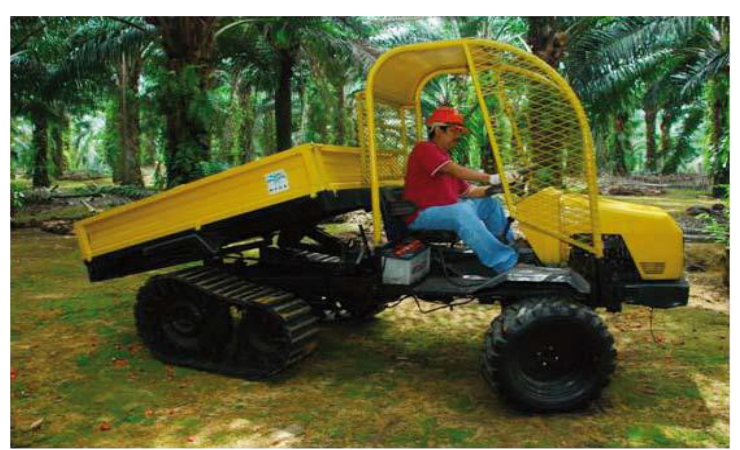

Fig.(10): A half-track machine tested in the field (Shuib et al., 2011a).

Apart from the standard front wheel steering, the 6WD transporter equipped with an additional steerable rear axle. This rear axle steering can be engaged and disengaged depending on need. If four-wheel steering mode is engaged, its turning radius would be reduced to half, making turning in a tight spot a lot easier. Another modernity of the 6WD which is the arm hinged to the chassis, thus allows it to swing up and down about the chassis so that all four wheels are always in contact with the ground. Through this characteristic, the 6WD transporter has the best traction on uneven land. The 6WD transporter is also equipped with a Grabber for picking. The 6WD transporter has a 45.3 HP Kubota V2203-E 4-cylinder diesel engine, a 41cc/rev EATON MD 72400 hydrostatic tandem pump and a $245 \mathrm{cc} / \mathrm{rev}$ CHAR LYNN 6000 series traveling motor. The overall dimensions of the 6WD transporter are $4850 \mathrm{~mm}$ (L) x $2030 \mathrm{~mm}$ (W) x $3050 \mathrm{~mm}(\mathrm{H})$. The transporter can be equipped with various agricultural implements to enhance traction while working under demanding field conditions, e.g., soggy areas or steep inclines. The achievable 6WD transporter outputs in the field are in the range from 18 to 28 ton per day (Shuib et al., 2009). This machine also does not have the ability to collect FFB loose fruits

Prime mover for soft ground areas such as 4wheel drive transporter is used as a good solution for peat soil (Fig. 11). Some specifications of this machine are $35.3 \mathrm{HP}$, transmission system using 5-speed gearbox, payload $500 \mathrm{~kg}$, fully-hydrostatic steering, permanently engaged 4-wheel drive, tires of four equal sizes 12.4-16-6 ply (traction lugged). The productivity of this machine is $12-16$ tons per day (Shuib et al., 2011b).

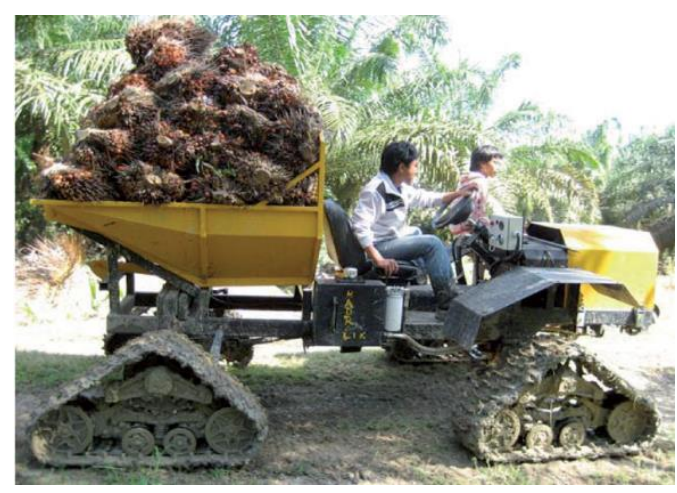

Fig. (11): The 4-wheel transporter during field testing (Shuib et al., 2011a).

MPOB and MIZOU introduced Rhyno, a multipurpose wheel type transporter for in-field collection of FFBs in peat soil, narrow terraces, undulating terrain and soggy ground conditions (Fig. 12). The Rhyno has a compact turning radius, and a hydraulically powered truck-type steering wheel which can easily shunt it along the undulating harvesting path. The oscillation pivot on its frame and excellent suspension system contribute to stability on uneven ground. Rhyno is capable of carrying $700 \mathrm{~kg}$ of FFB payload, 19 HP engine, transmission system includes 6-speed synchromesh, dumping by a hydraulic cylinder with high pivot and floatation tires. Productivity for this 
machine is 13-20 tons per day. The price was MYR 58,000 in 2013, and this is too expensive for smallholders (Deraman et al., 2013).

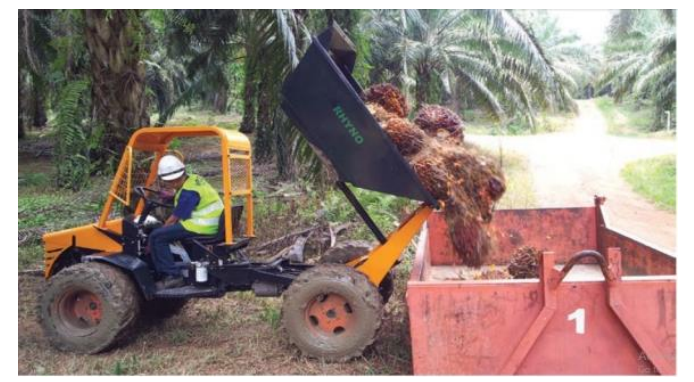

Fig. (12): Rhyno unloading fresh fruit bunches into the bin (Deraman et al., 2013).

Otowey is another in-field FFB transporter that was designed with an electronic weighing system consisting of a transporter and equipped with four load cells, one in each corner of its chassis just under the FFB hopper (Fig. 13). Weighing is automatically done, just by loading bunches in the hopper. The total weight of FFBs is shown on the panel, increasing as more and more FFBs are loaded. With the machine, the number of workers for yield recording could be reduced from three to two, enhancing the output of the harvesters by $96 \%$. Time and labour are significantly lowered with higher production and the data are also more accurate (Shuib et al., 2008).

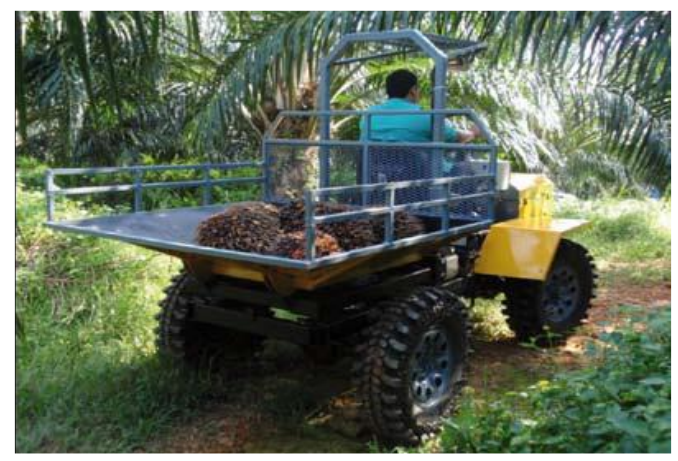

Fig. (13): The Otowey transporter (Shuib et al., 2011a).
Mobile bunch catcher MBC is designed to suit harvesting work and to catch loose fruits (Fig. 14). It is equipped with a big 'catcher' containing one FFB at the time. MBC also has hydraulic, mechanical equipment and is easy to drive and maneuver in harvesting path. Mobile bunch catcher machine can produce up to 4.8 (average) ton.day ${ }^{-1}$ equivalent to 208 bunches of FFBs with the consumption of 6 litters of fuel. Hectare coverage is about 2.7 hectares (average) per worker per day. This machine can also operate in specific topography (Awaludin et al., 2016b).

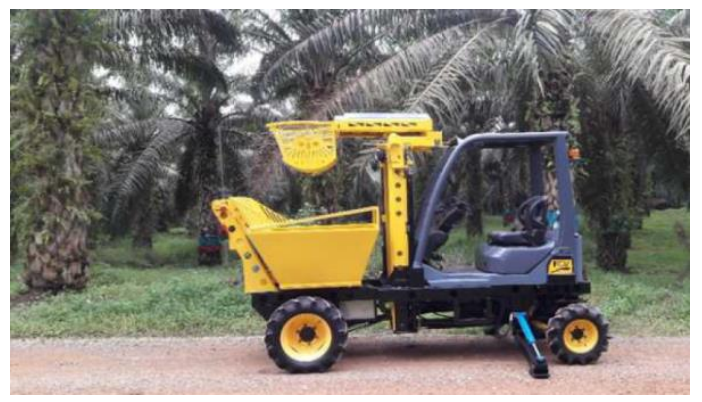

Fig. (14): Mobile Bunch Catcher MBC (Awaludin et al., 2016b).

\section{Machines for collecting the FFB loose fruits}

Many machines and equipment invented (Table 1) to collect and transfer the oil palm FFBs show good productivity (1.3-25 tons per day). Despite the good results, they still need to collect and load the FFBs manually. The machines that can collect and load mechanically are (Grabbie) mechanical FFB Loader, Machine System for in-field FFB Collection and Transportation, and Mobile Bunch Catcher (MBC) (Jahis \& Hitam, 1999); (El Pebrian and, Yahya 2013); (Awaludin et al., 2016a, b). Moreover, all these machines were unable to collect the loose fruits, except Mobile Bunch Catcher MBC. New machines 
have been developed to overcome the loose fruits problem (Table 2), and these innovations have successfully solved the problem.

\section{Vacuum suction machines for the collection of FFB loose fruits}

MPOB and Universiti Putra Malaysia developed a mechanical loose fruits collector using a direct suction technique with a separator in the pressure line (Fig. 15). The suction generated from an impeller attached to a pushcart fitted with a two-compartment container, one for fruits the other for debris. The debris collected with the fruits consists of particles of nearly the same weight as the fruits or where the length exceeds $50 \mathrm{~mm}$. Experiment conducted showed that the machine was able to collect an average of 1.0 to $1.2 \mathrm{~kg}$. per min with less than $10 \%$ debris. In the case of a manual collection, 0.7 to $1.4 \mathrm{~kg}$ per min of fruits could be collected, depending on the number of fruits per palm and whether they are scattered or heaped in one place.

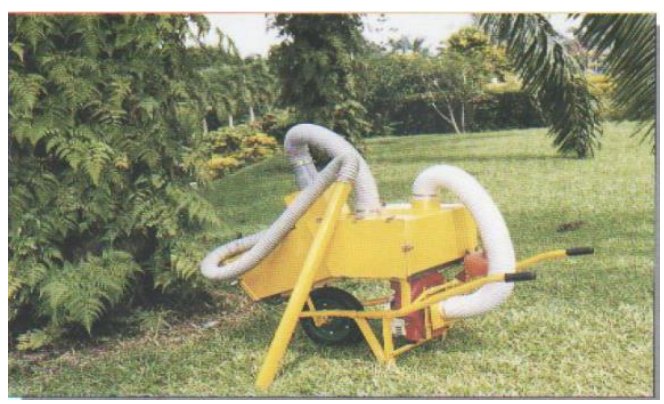

Fig. (15): Loose fruit collector (Hitam et al., 1995b).

Manual collection usually becomes more difficult if the fruits are scattered. On average, this machine can collect $300-400 \mathrm{~kg}$ of clean loose fruits per day. This machine is designed to collect loose fruits at the palm base only as the number of fruits there is comparatively small (Hitam et al., 1995b). Hence a massive machine would be required to collect the loose fruits at the collecting point where the number of loose fruits is very much higher (Hitam et al., 1995b).

The Mechanical loose fruit collector (Mk II) developed in 1999 (Fig. 16) has similar concept as that of the loose fruit collector in 1995 (Hitam et al., 1995b). The difference is that Mk II has broader coverage and capacity. The new design reduces labour requirements, reduces cost of production, increases productivity per worker and maximises fruit recovery.

The airspeed used to make air vacuum for this mechanical collector is $20-35$ meter per second for collecting the loose fruits. Air vacuum is developed using 1.6 liters air-cooled, one cylinder Yanmar diesel engine which can produce $6.04 \mathrm{HP}$, and having three-stage forward and one-stage reverse transmission. In a test joined by three workers (one operator and two sweepers). The productivity was found to be $1.5-1.7$ tons per day. However, from the commercial field trial, it was found that a higher suction power is required for a higher production rate. Therefore, this can be done by increasing the engine power. It is suggested that a closer look at other systems of collection should be considered to improve the system of loose fruit collection (Zamari et al., 1999).

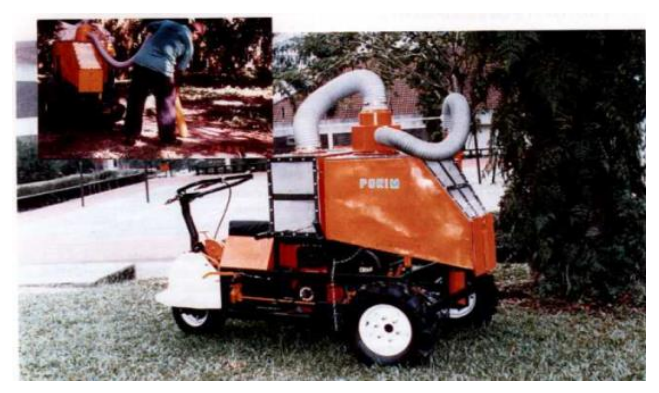


Fig. (16): Mechanical loose fruit collector (Mk II) (Zamari et al., 1999).

The disadvantage of the earlier suction method of loose fruit collection is the shortage of engine power, where the vacuum created by the engine is not strong enough to avoid throttling. In the new machine, the suction power has been increased to ensure that the fruits are readily absorbed into the barrel with minimal suction problem, that usually occurs during wet weather when the fruits are moist, which in turn slow down the collection process.

A cyclonic vacuum concept has the main advantage of constant suction power, in which loose fruits are absorbed into a cylindrical casing with conical shape barrel towards its bottom. The cylindrical shape would create a cyclone air once the fruits are absorbed in, with least contusion to the fruit. As the fruits circulate within the barrel/chamber, the larger fruits would separate at the bottom of the barrel (as it loses energy) while the lighter materials such as dried leaves would be blown out of the system. This technology is also able to separate the collected loose fruits and the debris into two layers in the vacuum chamber, hence producing clean loose fruits at the bottom of the barrel (Fig. 17). The vacuum is created by a fan placed into its casing where the output shaft is connected to a $9 \mathrm{HP}$ diesel engine by a series of pulley and belt system. The loose fruits are absorbed using the suction nozzle with a diameter ranging from 60 to $75 \mathrm{~mm}$. The advantages of this improvement are the loose fruits can be sucked faster, less burden to workers as they do not need to bend and carry loose fruit bags, and increase the workers' and plantation productivities. On average, the machine can collect 1200 to $1500 \mathrm{~kg}$ of clean loose fruits in a day. The use of this machine is very active in cases where the scattered fruits have been heaped at one place (Shuib et al., 2012).

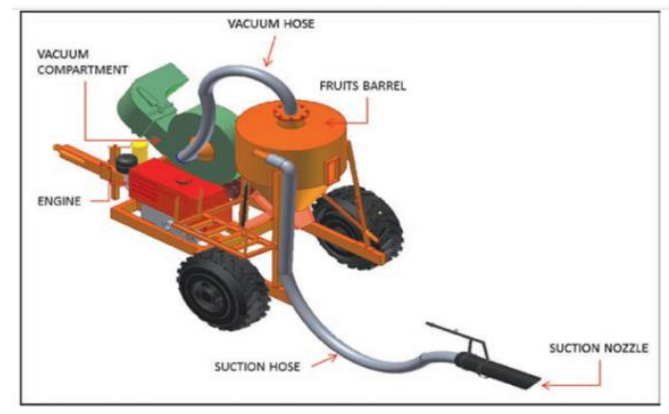

Fig. (17): Parts of the Oil Palm Loose Fruit Collector MK III (Shuib et al., 2012).

A new machine has been developed which keeps the vacuum concept (suction cyclone) as in the previous model (Shuib et al., 2012) (Fig. 18). This technology is also eligible for separating the collected loose fruits and the remains into two layers in the vacuum chamber hence producing clean loose fruits at the bottom of the fruit barrel. The machine is easy, and fast to operate. The additional mechanism that is improved involves the barrel, which now serves as a temporary storage area. The contents of the barrel occasionally emptied into another container that can keep up to $500 \mathrm{~kg}$ of fruits. Once the amount of fruits in the container reaches $500 \mathrm{~kg}$, the operator will lift and unload them into a mainline transport system either a waiting trailer, basket or sterilizer cage. Emptying the content is made easy with a hydraulic control lever. The concept and primary components of the machine is shown in fig. (20). The advantages of this machine are the loose fruits can be collected in short time with minimum back pain 
to labours as the operation can be carried out while standing.

It was found that the suction power was sufficient with an average air velocity of $40 \mathrm{~m}$ per second at $2000 \mathrm{rpm}$ engine speed. The engine horsepower was $25 \mathrm{HP}$ and the suction hose is $7 \mathrm{~m}$ in length @ $75 \mathrm{~mm}$ Dia. The machine is capable of collecting an average of 1500 to $2000 \mathrm{~kg}$ of clean loose fruits a day. With the proposed design, the machine is well integrated with the mainline transportation system, i.e., the sterilizer cage system (Shuib et al., 2017). Despite the advantages of this machine, it remains a separate process from the FFB transporting process. Thus, to fulfil the transporting process for FFB and its loose fruits, the two processes should be combined or integrated together.

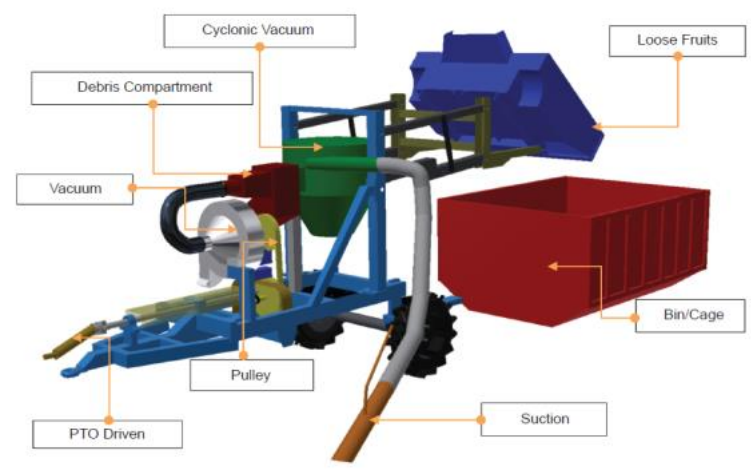

Fig. (18): Parts of the Oil Palm Loose Fruit Collecting Machine with Elevated Discharge Mechanism (LFC Mark IV) (Shuib et al., 2017).

\section{Roller Picker for collecting FFB loose fruits}

A study was carried out on the approaches of collecting and separating loose fruits as well as to design a cost-effective device for loose fruits collection. The Roller Loose Fruit Picker, or in short the Roller Picker (RP), collects loose oil palm fruits by picking and retaining the loose fruits in a case without tedious and labourious efforts (Fig. 19). It is designed to be manually operated and is practical and affordable (Deraman et al., 2009). The invention is an oval-shaped case made of a plurality of wires or rods. During operation, the RP is rolled with a little pressure against the ground causing the wires or rods of the case to split open and to trap the loose fruit inside the case. Once the loose fruits are entrapped inside, the wires or rods of the case will return to their normal position. All debris smaller than the spaces between the wires or rods will drop from the case, and therefore will result in only debrisfree loose fruits collected. Field trials carried out at the MPOB/UKM plantation showed that the RP was capable of collecting, on average, 30 to $60 \mathrm{~kg}$ per hour of fruit, depending on the ground conditions. The collected fruits were not damaged and were free of debris.

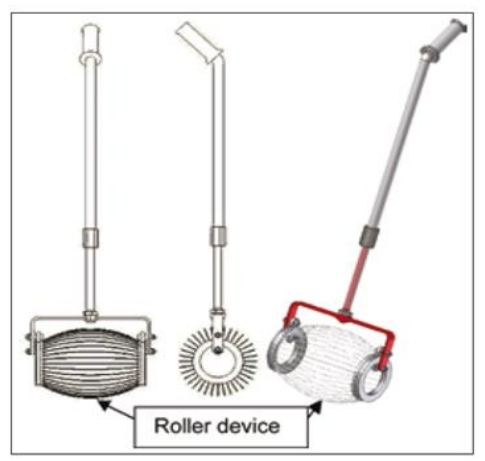

Fig. (19): The RP and its specifications (Deraman et al., 2009).

The benefits of using the Roller Picker are it reduces the back pain of the loose fruit collector as the task is physically taxing, provides debris-free collected loose fruits, and increased palm oil quality achieved at the mill. However, the tool is still low in the rate of 
productivity and only collect small stones which have the same size as the fruit itself.

\section{Robotic machine for collecting FFB loose fruits}

Nadzri \& Ahmad (2016) reported on a robotic machine for collecting FFB loose fruits named as Roller Picker Robot or ROPICOT 1.0. This robot performs the rolling tasks with its robotic mechanism. In performing this task, three main parts have been identified namely the input, processing unit and the output. The wireless controller is applied as a device to give an input data for the system, and the controller will supply input to the Arduino Mega to operate. The input signal will transfer when the button is pressed by the user. The prototype will collect dispersed oil palm loose fruits on different ground conditions with expected trash content of less than $10 \%$. The prototype moves forward, backward, left and right according to the orders from the microcontroller.

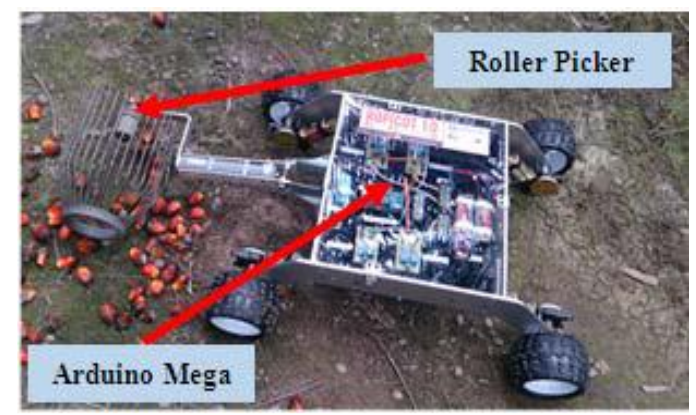

Fig. (20): Roller picker robot (ROPICOT 1.0) on real surface condition in oil palm plantation (Nadzri \& Ahmad, 2016).

The machine is also available on four (4) tires that are able to work on various ground conditions and will utilize roller picker to collect the loose fruit. An overview of this proposed solution is illustrated in fig. (20). The prototype tested gave good results in movement, quantity, quality and stability during collecting of loose fruits. The machine can collect $2 \mathrm{~kg}$ within 120 seconds.

\section{Challenges}

All the machines reviewed above, generally are able to reduce the actual time for evacuating FFBs and collecting loose fruits from the plantation area to the collecting point and hence, improve their efficiency as well as productivity. Despite that, the transporting and loose fruits collecting processes by those machines are operating separately from each other, which means more time will be needed to complete the task and more machines to be used. All transporting machines are not able to eliminate loose fruits problem and require loose fruits collecting machines to fulfil the collection and in-field transportation of FFBs. With additional machines required for the operations, there will be more fuel consumption, pollution and time wastage, except for the Mobile Bunch Catcher, MBC. However the MBC too has a limited height of $5 \mathrm{~m}$ and the catcher cannot handle more than $100 \mathrm{~kg}$ weight. Furthermore, the MBC machine needs to go around the oil palm tree which means more time to travel and manoeuvre. Table (2) summarizes the problems of in-field transporting machines in evacuating and transporting FFBs, and collecting the oil palm loose fruits. 
Table (2): Problems of in-field transporting machines in evacuating and transporting FFBs and collecting of oil palm loose fruits.

\begin{tabular}{|c|c|c|c|}
\hline Activities & Type of machines or equipment & $\begin{array}{l}\text { Current } \\
\text { Problems }\end{array}$ & $\begin{array}{l}\text { Source of } \\
\text { Reference }\end{array}$ \\
\hline \multirow[t]{2}{*}{$\begin{array}{l}\text { Transport } \\
\text { FFBs }\end{array}$} & $\begin{array}{l}\text { - Mobile Bunch } \\
\text { Catcher (MBC) }\end{array}$ & $\begin{array}{l}\text {-Limited in } \\
\text { capacity } 1.3-2.4 \text { tons per day }\end{array}$ & $\begin{array}{l}\text { (Awaludin et al., } \\
\text { 2016b) }\end{array}$ \\
\hline & $\begin{array}{l}\text { - Three Wheeler Machine } \\
\text { - Wakfoot MK2 } \\
\text { - Compact Transporter } \\
\text { - Primer Move Track } \\
\text { - Multipurpose Wheel Type } \\
\text { Transporter (Rhyno) } \\
\text { - Mechanical FFB Loader } \\
\text { (Grabbie) } \\
\text { - Machine System for In-Field FFB } \\
\text { Collection and Transportation } \\
\text { - Mobile Oil Palm Fresh Fruit } \\
\text { Bunch Catcher }\end{array}$ & $\begin{array}{l}\text { - Limited in working height } \\
\text { range }(3-5 \mathrm{~m}) \text {. } \\
\text { - Limited in FFB catch } \\
\text { weight }(100 \mathrm{~kg}) \text {. }\end{array}$ & $\begin{array}{l}\text { (Jahis \& Hitam, } \\
\text { 1999); (Hitam \& } \\
\text { Shuib, 2000); } \\
\text { (Deraman et al., } \\
\text { 2006); (Shuib et } \\
\text { al., 2011a, b); } \\
\text { (Deram an et al., } \\
\text { 2013); (El } \\
\text { Pebrian } \\
\text { Yahya, 2013); } \\
\text { (Awaludin et al., } \\
\text { 2015) } \\
\text { (Awaludin et al., } \\
\text { 2016b) }\end{array}$ \\
\hline \multirow[t]{2}{*}{$\begin{array}{l}\text { Collect } \\
\text { Loose } \\
\text { Fruits }\end{array}$} & $\begin{array}{l}\text { - Loose Fruit Collector } \\
\text { - Mechanical Loose Fruit Collector } \\
\text { (MKII) }\end{array}$ & $\begin{array}{l}\text { - Low productivity } 0.5-1.2 \\
\text { kg. per min } \\
\text { - Trash }<10-15 \%\end{array}$ & $\begin{array}{l}\text { (Nadzri } \& \\
\text { Ahmad, 2016) }\end{array}$ \\
\hline & - Manual Roller Picker & $\begin{array}{l}\text { - Long time and low } \\
\text { productivity } 30-60 \mathrm{~kg} \text { per } \\
\text { hour. }\end{array}$ & \\
\hline
\end{tabular}

In view of the above challenges, there is a need for a machine that can integrate all operations namely harvesting, transporting FFBs and collection of loose fruits, in one go without injuring the fruits to maintain oil quality. This new machine should consider all problems stated in Table (2). In addition, there is potential in using biodiesel as power supply via the battery system to replace diesel in the internal combustion engine of the tractor.

Currently this is still under study by the government. The current technology is not completely implemented throughout the palm oil industry since no uniform policy is being enforced by the government. Usage has been voluntary based on acreage and financial capability of respective agencies. The employment of foreign labour who are willing to accept lower salary scale has somewhat hampered the use of mechanisation in the oil palm plantations. For the implementation to be successful, the government should encourage mechanization and increase the salary scale to make it attractive for the local workers apart from financial support for local agricultural machinery industries to survive. Research on the design and development of an integrated machine combining harvesting, transporting 
FFBs and collection of loose fruitlets all in a single operation should be pursued.

\section{Conclusions}

Based on the machines developed earlier by various researchers, most in-field transporting machines work in the range of 1.3-25 tons per day. Also, most of the collection and evacuation machinery for FFBs must be manually loaded, which means more workers and human effort are required except for Grabbi, Machine System for in-field FFB Collection and Transportation, and Mobile Bunch Catcher MBC. Thus, this negatively affects the productivity of these machines as well as physical hazards to workers. Moreover, in-field transporting machines are not able to collect the loose fruits as a result of FFBs falling to the ground except for Mobile Bunch Catcher, MBC. Many loose fruit collecting machines have been developed using several techniques including vacuum suction, roller picker, and robotic collector achieving 30-70 kg per hour. However, in-field FFB transporting machines work separately, and this would require more machines and more time to complete the task. This would increase the production cost, increase pollution, and more soil compaction caused by the repetition of machines movement in the field. Hence when developing mechanical in-field transport, factors such as efficiency, effectiveness, and convenience need to be considered. Based on the above review, the criteria for a successful in-field oil palm FFB and loose fruits transporter in an oil palm plantation include low ground pressure and lightweight; stable at maximum horizontal and vertical outreach, and able to work on different slopes; good infield traveling speed between $1-25 \mathrm{~km}$ per hour; reduce the number of workers; safe, efficient and ergonomic use for the operator; multi-purpose (loading, transporting or evacuating FFBs in the plantation area) and reduce injury to the FFBs to maintain oil quality.

\section{Acknowledgements}

The authors would like to acknowledge the Department of Biological and Agricultural Engineering and the library of the Faculty of Engineering, Universiti Putra Malaysia for their support. The authors would also like to thank Malaysia Palm Oil Board (MPOB) library for their help to get sources related to this work. Finally, the first author would like to acknowledge University of Mosul for giving the opportunity and scholarship to complete his Ph. D. study at University Putra Malaysia.

\section{References}

Akande, F., Kazeem, O., Oluwole, O., \& Gbolahan, B. (2013). Level of oil palm production mechanization in selected local government areas of Oyo and Osun States, Nigeria . Innovative System Design and Enginneering, 4, 36-40. https://www.iiste.org/Journals/index.php/ISDE/arti cle/view/6250

Awaludin, A., Syed S. S. A., Abdul H. Z. A., \& Azahah A. (2016a). Conceptual of mobile oil palm fresh fruit bunch catcher. International Journal of Agriculture Innovations and Research, 4, 11591163.

https://ijair.org/index.php/issues?view=publication $\&$ task $=$ show $\& \mathrm{id}=766$

Awaludin, A., Syed, S. , Abdul Halim, Z. A., \& Mohd, R. N. (2015). Performance study of an oil palm fresh fruit bunch three wheeler evacuation machine. The Online Journal of Science and Technology, 5, 46-53. https://doi.org/10.1016/j.rser.2010.07.062

Awaludin, A., Syed S. S. A., Abdul Halim Z. A., \& Rasidi I. (2016b). Performance study of an oil palm mobile bunch catcher. International Journal of Engineering Innovation \& Research, 5, 384-388. https://ijeir.org/administrator/components/com_jres 


\section{Aljawadi et al. / Basrah J. Agric. Sci., 34(Special Issue 1):119-137, 2021}

earch/files/publications/IJEIR_2149_FINAL.pdf

Deraman, M. S., Hitam, A., \& Mohammad, B. S. (2004). Cableway system for oil palm FFB evacuation. MPOB Information Series TT No. 218, 3-6.

http://palmoilis.mpob.gov.my/publications/TOT/TT -218.pdf

Deraman, M. S., Shuib, A. R., \& Mohd, S. J. (2009). Roller-type oil palm loose fruit picker. $M P O B$ Information Series TT No. 419, 1-2. http://palmoilis.mpob.gov.my/publications/TOT/TT -419.pdf

Deraman, M. S., Hitam, A., Shuib, A. R.; Mohamed, A. (2006). Compact Transporter for in-Field Activities. MPOB Information Series TT No. 316, 2-3.

http://palmoilis.mpob.gov.my/publications/TOT/TT -316.pdf

Deraman, M.S., AbdRahim, S., Zaprunnizam, M. A., Aminulrashid, M., \& Hartini, M. D. H. (2013). Rhyno: A Multipurpose Wheel type transporter for oil palm Activities on undulating terrain and soggy Areas. MPOB Information Series TT No. 535, 2932.

El Pebrian, D.,\& Azmi Y. (2013). Mechanized System for in-Field Oil Palm Fresh Fruit Bunches Collection-Transportation. AMA-AGRICULTURAL MECHANIZATION IN ASIA, AFRICA, AND LATIN AMERICA, 44, 7-14. https://www.researchgate.net/publication/27465397 6_Mechanized_System_for_in-

Field_Oil_Palm_Fresh_Fruit_Bunches_CollectionTransportation

Hitam, A., \& Ibrahim, A. (1992). The gabber. An important development towards reducing dependence on labour. MPOB Information Series TT No. 03 .

Hitam, A., \& Abd Rahim S. (1995a). The Grabber Mark 2 An Automatic Mechanical Loader. $M P O B$ Information Series TT No. 18, 1-2. http://palmoilis.mpob.gov.my/publications/TOT/TT -18.pdf

Hitam, A., \& Abd Rahim S. (2000). The Wakfoot MK 2 an Infield FFB transport for peat area. $M P O B$ Information Series TT No. 78, 1-2. http://palmoilis.mpob.gov.my/TOTV3/wpcontent/uploads/2020/02/tt78.pdf
Hitam, A.; \& Deraman, M. S. (2001a). Motorcycle Trailer: An important to assist oil palm smallholder for field activities. $M P O B$ Information Series TT No. $\quad 107, \quad 1-4$. http://psasir.upm.edu.my/id/eprint/77751/1/FK\%20 2019\%2050\%20IR.pdf

Hitam, A., \& Deraman, M. S. (2001b). Powered wheelbarrow: An implement to assist Oil palm field activities. MPOB Information Series. TT No. 108, $1-2$.

Hitam, A., Ahmad, Z. M. Y., \& Mohd, S. (1995b). Loose Fruit collector. MPOB Information Series TT No. $19, \quad 1-2$. https://journal.ump.edu.my/ijets/article/download/2 909/644/

Ismail, W. I. W. (2010). Research and Development of Oil Palm Harvester Robot At Universiti Putra Malaysia. International Journal of Engineering and Technology, 7 , 87-94. http://ijet.feiic.org/journals/2010Issue\%202\%20$\% 2006 . p d f$

Jahis, S., \& Ahmad, H. (1999). Mechanical FFB loader for short palm-the grabbie. MPOB Information Series $\quad T T \quad$ No. 59, 1-2. http://palmoilis.mpob.gov.my/publications/TOT/TT $-59 . p d f$

Jelani, A., Desa, A., Ahmad, H., Azmi, Y., \& Johari, J. (1998). Force and energy requirments for cutting oil palm frond. Journal of Oil Palm Research, 10, $10-24$.

Mahat, S. B.A. (2012). The Palm oil industry from the perspective of sustainable development: A case study of Malaysian palm oil industry. M. Sc. Thesis. Ritsumeikan Asia Pacific University Japan. https://www.semanticscholar.org/paper/The-PalmOil-Industry-From-The-Perspective-of-A-of-BintiMahat/a8fbe484de2bfacbb17355e9af6638b8eab15 dfc

Nadzri, M. M. M., \& Ahmad, A. (2016). Roller picker robot (ROPICOT 1.0) for loose fruit collection system. ARPN Journal of Engineering and Applied Sciences, $\quad 11, \quad 8983-8986$. http://www.arpnjournals.org/jeas/research_papers/r p_2016/jeas_0716_4712.pdf

Norzan, M. L., Shahriman,A. B., Shamsul, B. M. T., Deros, B. M., Rambely, A.S. Khairunizam W., Ng, Y. G., Mohd, A., Cheng, E. M., Shafriza, N. B., \&

The $5^{\text {th }}$ International Conference on Agricultural and Food Engineering (CAFEi) 2021 


\section{Aljawadi et al. / Basrah J. Agric. Sci., 34(Special Issue 1):119-137, 2021}

Zaaba, S. K. (2014). Overcoming issues of oil palm plantations manual work with ergonomic and engineering considerations. Australian Journal of Basic and Applied Sciences, 8, 393-397.

Nur, S. M. N., Baba, M. D., \& Norani, N. (2014). Barriers of Adopting Harvesting Technology In Malaysian Oil Palm Industry. Australian Journal of Basic and Applied Sciences, 8, 198-200.

Onwude, D. I., Rafia, A.,Chandima, G., \& Norhashila H. (2016). Mechanisation of large-scale agricultural fields in developing countries - a review. Journal of the Science of Food and Agriculture, 96, 39693976. https://doi.org/10.1002/jsfa.7699

Otieno, N. E., Xeuping, D., Daniele, D. B., Abbassi, B., Elise, S., Marouan, R., Lise, J. (2016). Palm oil production in Malaysia: An analytical systems model for balancing economic prosperity, forest conservation and social welfare. Agricultural Sciences, $\quad 7, \quad 55-69$. https://doi.org/10.4236/as.2016.72006-418.pdf

Shuib, A., \& Ahmad, H. (2002). Half-track machine for all weather in-field collection of oil palm fresh fruit bunches (FFB). MPOB Information Series TT No. 136, 1-2. http://palmoilis.mpob.gov.my/publications/TOT/tt1 36.pdf

Shuib, A., Mohd, R. Kh., \& Mohd, S. D. (2011a). Innovation and technologies for oil palm mechanization. In Further advances in oil research (2000-2010), 570-597.

Shuib, A., Azmi, Y., Wan, I. W. I., \& Desa, A. (2009). A six-wheel-drive transporter for oil palm FFB evacuation. MPOB Information Series TT No. 418, $1-2$. http://palmoilis.mpob.gov.my/publications/TOT/TT

Shuib, A., Mohd, R. Kh., Mohd S. D., \& Aminulrashid, M. (2011b). Prime mover for soft ground areas. МРOB Information Series TT No. 489 , $1-4$. http://palmoilis.mpob.gov.my/publications/TOT/TT
$-489 . p d f$

Shuib, A., Mohd, R. Kh., Mohd, S. D., \& Aminulrashid, M. (2012). Oil palm loose fruits collector (MK III). MPOB Information Series TT No. 505, 3-6. http://palmoilis.mpob.gov.my/publications/TOT/TT $-505 . p d f$

Shuib, A., Mohd, R. Kh., Mohd, A. B., Aminulrashid, M. \& Nordin, S. (2017). Oil palm loose fruit collecting machine with elevated discharge mechanism (LFC Mark IV). MPOB Information Series. $\quad T T \quad$ No. 612, 3-6. http://palmoilis.mpob.gov.my/publications/TOT/tot 2017/TT612-Rahim\%20Shuib.pdf

Shuib, A., Norman, K., Mohd, H. H., Wahid, O., Idris, A., Siti, R. A. A., Ahmad, T. M., \& Amirulrashid, M. (2008). Otowey: an in-field FFB transporter with electronic weighing system. $M P O B$ Information Series. TT No.408, 3-6.

Yusof, A. Z. M. D., Ahmad, H. \& Mohd, B. W. (1999). Mobile ramb-for mainline loading of oil palm fresh fruit bunch (FFB). MPOB Information Series TT No. 75, 1-2. http://palmoilis.mpob.gov.my/TOTV3/tt-no-75mobile-ramp-for-mainline-loading-of-oil-palmfresh-fruit-bunches/

Yusoff, I. S. M., Shamsul, B. M., Aini, M. S., Yee, G. N. G., \& Mori, I. (2014). Oil palm workers: designing ergonomics harvesting tool using user centered design approach to reducing awkward body posture by catia simulation. Iranian Journal of Public Health, 43, 72-80. https://ijph.tums.ac.ir/index.php/ijph/article/view/4 866

Zamari, A. M. Y., \& Ahmad, H. (1999). Mechanical loose fruit collector (MK II). MPOB Information Series. TT No. 57, 1-4. Retrieved from https://www.yumpu.com/en/document/view/19281 793/mechanical-loose-fruit-collector-mk-iipalmoilis 